\title{
mRNA sequencing of Eucalyptus urograndis trees supplemented with flavonoids shows changes on metabolic process and decrease of lignification
}

\author{
Jorge Lepikson-Neto ${ }^{1 *}$, Leandro Nascimento ${ }^{1}$, Maria Carolina Scatollin', Wesley Marques', Marcela Salazar ${ }^{1}$, \\ Eduardo Camargo ${ }^{1}$, Ramon Vidal ${ }^{2}$, Danieli Gonçalves ${ }^{1}$, Goncalo Pereira ${ }^{1}$ \\ From IUFRO Tree Biotechnology Conference 2011: From Genomes to Integration and Delivery \\ Arraial d'Ajuda, Bahia, Brazil. 26 June - 2 July 2011
}

\section{Background}

The flavonoids, naringenin-chalcone and narigenin, are intermediates in phenylpropanoid metabolism in plants, occupying the central position as primary intermediates in flavonoid biosynthesis and are synthesized by chalcone synthase (CHS) and chalcone isomerase (CHI) respectively.[1] It has been reported that supplementation of narigenin-chalcone and narigenin can inhibit the activity of 4CL in vitro, and suppress the growth and reduce lignin content in gramineous plants, while 4CL suppression affected plant phenotype and resulted on dwarfed trees on Pinus[2], and its down-regulation promoted enhanced growth phenotypes on transgenic aspens trees [3], also CHS expression controls flavonoid synthesis and reduced size phenotype on arabidopsis. [4] Eucalyptus is the main source of biomass for pulp and paper industries therefore it's imperative to study the influence of flavonoid supplementation on Eucalyptus and what kind of overall impact it can have on plant development, especially wood formation and gene expression.

\section{Methods}

\section{Plant Material}

1 month Eucalyptus plantlets were divided into 3 groups with 25-30 individuals per group. Groups were given normal root induced nutritive solutions (Group 1) and added narigenin-chalcone (group 2) and narigenin (group 3). Treatment lasted 5 months with regular

\footnotetext{
* Correspondence: lepiksonneto@gmail.com

'Laboratório de Genômica e Proteômica State University of CampinasUNICAMP, Brazil

Full list of author information is available at the end of the article
}

supplementation. Samples were then collected and properly stored.

\section{Histhochemical analyses}

Stem samples were harvested and fixed in FAA for at least $24 \mathrm{~h}$. Sections were double stained with $1 \%$ alcoholic Safranin O and 1\% aqueous Astra Blue. Hand sectioned tissue samples from the same material were stained with Mäule reagent: $1 \% \mathrm{KMnO} 4$ for $15 \mathrm{~min}, 2 \%$ $\mathrm{HCl}$ for 5 min, and $2 \mathrm{~N} \mathrm{NH} 4 \mathrm{OH}$ solution. Sections were observed with an Olympus BX51 microscope under white light, and the images were obtained with DP-72 digital camera and Image Pro Plus 6.3 software.

\section{mRNA Sequencing}

RNA was extracted from xylem tissue according to [5] and mRNA libraries were prepared following instructions from the Illumina mRNA-Seq Prep Kit. Three distinct libraries were generated: E.urograndis plantets supplemented with narigenin-chalcone; narigenin; and control solution, containing 34,157,958 (65,75\% mapped); 33,743,449 (64,80\% mapped); 32,076,198 (65,09\% mapped) reads, (reads size approximately $36 \mathrm{pb})$.

\section{Assembling and annotation}

We assembled 167,271 ESTs (130,290 from Genolyptus and 36,981 from NCBI) from several species and tissues using the program CAP3. [6] The assembly produced 53,412 unigenes (18,098 contigs and 35,314 singlets).

All unigenes were automatic annotated using the BLAST [7], including: non-redundant (NR) database of NCBI, pfam [8]. Moreover, we performed a functional annotation using the BLAST2GO software. [9] 
The RNA-Seq reads were aligned against the assembled unigenes using the SOAP2 aligner [10] In order to perform the differential expression analysis between libraries, a normalization and statistical pipeline were applied using DEG-seq software [11] considering 99\% of confidence rate (cut-off of 0.01 ).

\section{Results and discussion}

Dual staining with Astra-blue and safranin-O histochemical analysis show, that both groups of plants treated with flavonoids exhibit a much greater blue stain, typical of celluloses content, when compared to control plants, while exhibiting a lesser amount of the red/purple stain related to phenolics compounds. The Mäule color reaction which provides an effective method for the detection of syringyl units, show an increase of $\mathrm{S}$ lignin content on both group of plants supplemented with narigenin and narigenin-chalcone. mRNA sequencing shows drastic changes on genes related with flavonoid sinhtesys, annotated contigs for those genes presented a much lower expression than control groups. Almost all genes from the phenylpropanoidpathway presented lower expression on treated groups, with genes at the beginning of the pathway presenting the most noteworthy reduction, while genes at the end of the pathway presented higher expression on treated groups which is interesting as it can suggest a shift from guaiacyl to syringyl monolignols increasing lignin solubility. Gene Onthology annotation shows significant differences among a number of metabolic process, including cell growth, cell division and response to stress. Among the most expressed genes were found heat-shock proteins, dehydrins and many no-hits. It is clear that supplementation with flavonoids alter gene expression especially regarding lignin biosynthesis.

\footnotetext{
Author details

'Laboratório de Genômica e Proteômica State University of CampinasUNICAMP, Brazil. 'Laboratório Nacional de Biociências - CNPEM/ABTLuS, Brazil.
}

Published: 13 September 2011

\section{References}

1. Boland $\mathrm{M}$, Wong E: Purification and kinetic properties of chalconeflavanone isomerase from soya bean. Eur J Biochem 1975, 50(2):383-389.

2. Wagner A, Ralph J, Akiyama T, Flint H, Phillips L, Torr K, Nanayakkara N, Te Kiri L: Exploring lignification in conifers by silencing hydroxycinnamoylCoA:shikimate hydroxycinnamoyltransferase in Pinus radiata. In Proc Natl Acad Sci. Volume 104. USA; 2007:(28):11856-61.

3. Hu WJ, Harding SA, Lung J, Popko JL, Ralph J, Stokke DD, Tsai CJ, Chiang VL: Repression of lignin biosynthesis promotes cellulose accumulation and growth in transgenic trees. Nat Biotechnol 1999, 17:808-812.

4. Besseau S, Hoffmann L, Geoffroy P, Lapierre C, Pollet B, Legrand M: Flavonoid accumulation in Arabidopsis repressed in lignin synthesis affects auxin transport and plant growth. Plant Cell 2007, 19:148-162.
5. Le Provost G, Herrera R, Paiva J, Chaumeil P, Salin F, Plomion C: A micromethod for high throughput RNA extraction in forest trees. Biological Research 2007, 40:291-297.

6. Huang X, Madan A: CAP3: A DNA Sequence Assembly Program. Genome Res 1999, 9:868-877.

7. Altschul SF, Madden TL, Schaffer AA, Zhang J, Zhang Z, Miller W, Lipman DJ: : Gapped BLAST and PSI-BLAST: a new generation of protein database search programs. Nucl. Acids Res 1997, 25(17):3389-3402.

8. Bateman A, Birney E, Cerruti L, Durbin R, Etwiller L, Griffiths-Jones S, Howe KL, Marshall M, Sonnhammer ELL: The Pfam Protein Families Database. Nucl. Acids Res 2002, 30(1):276-280.

9. Conesa A, Gotz S, García-Gómez JM, Terol J, Talón M, Robles M: Blast2GO: a universal tool for annotation, visualization and analysis in functional genomics research. Bioinformatics 2005, 21(18):3674-3676.

10. Li R, Yu C, Li Y, Lam T-W, Yiu S-M, Kristiansen K, Wang J: SOAP2: an improved ultrafast tool for short read alignment. Bioinformatics 2009, 25(15):1966-1967.

11. Wang L, Feng $Z$, Wang $X$, Wang $X$, Zhang $X$ : DEGSeq: an $R$ package for identifying differentially expressed genes from RNA-seq data. Bioinformatics 2010, 26(1):136-138.

doi:10.1186/1753-6561-5-S7-P118

Cite this article as: Lepikson-Neto et al:: mRNA sequencing of Eucalyptus urograndis trees supplemented with flavonoids shows changes on metabolic process and decrease of lignification. BMC Proceedings 20115 (Suppl 7):P118.

\section{Submit your next manuscript to BioMed Central and take full advantage of:}

- Convenient online submission

- Thorough peer review

- No space constraints or color figure charges

- Immediate publication on acceptance

- Inclusion in PubMed, CAS, Scopus and Google Scholar

- Research which is freely available for redistribution 